\title{
FIRST OCCURRENCE OF THE GIANT SHARK CARCHAROCLES MEGALODON (AGASSIZ, 1843) (LAMNIFORMES; OTODONTIDAE) AT BUENOS AIRES PROVINCE, ARGENTINA
}

\author{
JULIETA DE PASQUA (10 \\ Laboratorio de Anatomía Comparada y Evolución de los Vertebrados, Museo Argentino de Ciencias Naturales \\ "Bernardino Rivadavia", Av. Ángel Gallardo 470 (C1405DJR), Buenos Aires, Argentina. \\ julietadepasqua@gmail.com
}

\section{FEDERICO AGNOLIN (D)}

Laboratorio de Anatomía Comparada y Evolución de los Vertebrados, Museo Argentino de Ciencias Naturales"Bernardino Rivadavia", Av. Ángel Gallardo 470 (C1405DJR), Buenos Aires, Argentina.

Fundación de Historia Natural "Félix de Azara", Departamento de Ciencias Naturales y Antropología, Universidad Maimónides, Hidalgo 775 (C1405BDB), Buenos Aires, Argentina. fedeagnolin@yahoo.com

\author{
ALEXIS M. ARANCIAGA ROLANDO (1) \\ Laboratorio de Anatomía Comparada y Evolución de los Vertebrados, Museo Argentino de Ciencias Naturales \\ "Bernardino Rivadavia", Av. Ángel Gallardo 470 (C1405DJR), Buenos Aires, Argentina. \\ mauro.aguido@hotmail.com
}

\section{SERGIO BOGAN ID}

Fundación de Historia Natural "Félix de Azara”, Departamento de Ciencias Naturales y Antropología, Universidad Maimónides, Hidalgo 775 (C1405BDB), Buenos Aires, Argentina. sergiobogan@yahoo.com.ar

\section{DIEGO GAMBETTA (D)}

Museo Mar de Ajó, Mar de Ajó, Lebensohn 566 (CP7109), Buenos Aires, Argentina.

diegohg27@yahoo.com.ar

\begin{abstract}
Carcharocles megalodon is considered a macropredatory shark that inhabited the seas around the world from middle Miocene to late Pliocene. In Argentina, it has only been formally recorded at two localities. Here, we report the first record for this taxon in the Buenos Aires Province. This occurrence is based on an isolated tooth recovered on the beach at the Punta Médanos locality, which lacks clear stratigraphic context. Based on the regional geology, the specimen probably came from Pliocene beds. Its size indicates that it probably belongs to a juvenile individual.
\end{abstract}

Keywords: Carcharocles megalodon, macropredatory shark, fossil teeth, Mar de Ajó.

RESUMO - Carcharocles megalodon é considerado um tubarão macropredador que habitou os mares ao redor do mundo desde o Mesomioceno até o Neoplioceno. Na Argentina, a espécie só foi formalmente registrada em duas localidades. Aqui, relatamos o primeiro registro desse táxon na Província de Buenos Aires. Essa ocorrência é baseada em um dente isolado recuperado na praia da localidade de Punta Médanos, que carece de contexto estratigráfico claro. Com base na geologia da região, o espécime provavelmente veio de camadas do Plioceno. Seu tamanho indica que provavelmente pertence a um indivíduo jovem.

Palavras-chave: Carcharocles megalodon, tubarão macropredatório, dentes fósseis, Mar de Ajó. 


\section{INTRODUCTION}

Carcharocles megalodon (Agassiz, 1843) is considered a macropredatory shark that inhabited warm marine waters all around the world from the middle Miocene to late Pliocene (Applegate \& Espinosa-Arrubarrena, 1996; Gottfried et al., 1996; Purdy, 1996; Pimiento et al., 2010; 2013; 2016; Cappetta, 2012; Pimiento \& Clemens, 2014; Boessenecker et al., 2019). Because of its gigantic size and morphological distinctiveness, C. megalodon is one of the best-known fossil sharks (Keyes, 1972). Based on available fossils, numerous authors estimate that the size of C. megalodon ranged between 15 to $18 \mathrm{~m}$ long (Gottfried et al., 1996; Pimiento \& Balk, 2015; Shimada, 2019; Cooper et al., 2020). As is the case of most Neogene sharks, its fossil record is restricted to isolated teeth and vertebral centra (Gottfried et al., 1996; Reolid \& Molina, 2015).

Several fossiliferous deposits around the world yield teeth of Carcharocles megalodon and, for this reason, it is currently considered that this species had a global geographical distribution (Uyeno et al., 1989; Purdy et al., 2001; Reolid \& Molina, 2015; Pimiento et al., 2016). However, the published reports of C. megalodon in Argentina are scarce and restricted to the middle Miocene Paraná Formation near to Paraná city, Entre Ríos Province (Frenguelli, 1920; Cione, 1978; Cione et al., 2012) and from the mid-upper Miocene beds of Puerto Madryn Formation, Chubut Province, Patagonia (Cione et al., 2011). The goal of this study is to document the first record of C. megalodon from the Buenos Aires Province, discuss the stratigraphy of the area it was found in, and calculate the total length and body mass of the shark the tooth came from.

\section{MATERIAL AND METHODS}

For descriptive purposes, we follow the nomenclature of Applegate \& Espinosa-Arrubarrena (1996) (modified from Applegate, 1965). The determination of the life stage of the individual was made following the analysis of Pimiento et al. (2010).

The measurements (Figure 1D) were taken with a digital caliper with $0.01 \mathrm{~mm}$ precision. Crown height $(\mathbf{C H})$, crown width $(\mathbf{C W})$ and tooth height (TH) were taken following the criteria of previous authors (Hubbell, 1996; Shimada, 2002; Reolid \& Molina, 2015; Viciano et al., 2018). For the determination of the position of the tooth within the jaw, we used the reconstructed dental series of Shimada (2002) and Pimiento et al. (2010). To estimate the total length of the individual, we applied the formula of Shimada (2002) and for body mass we followed Gottfried et al. (1996). Regarding the formula of Shimada (2002) (Table 1), the author has encouraged the use of upper anterior teeth to estimate the TL over other teeth when possible, but it does not mean that the estimations with non-upper teeth are wrong, they are not as accurate. Regrettably, in our case we only have one upper lateral tooth, and we did all the estimations based on this element.
Due to the limited taxonomical information of available specimens, the phylogenetic position of Carcharocles megalodon is disputed. Studies originally proposed that it was closely related to the great white shark (Carcharodon carcharias) and assigned it to the same genus within the family Lamnidae (Applegate \& Espinosa-Arrubarrena, 1996; Gottfried et al., 1996; Purdy, 1996). However, more recent studies indicate that $C$. megalodon belongs to another lineage. A detailed study of its teeth indicates that it most probably belongs in the family Otodontidae, within the genus Carcharocles (Jordan \& Hannibal, 1923; Casier, 1960; Gluckman, 1964; Cappetta, 1987; Ward \& Bonavia, 2001; Nyberg et al., 2006; Ehret et al., 2009). Another hypothesis indicates that it should be placed among otodontids and considered as part of the genus Otodus (Shimada et al., 2017; Boessenecker et al., 2019; Cooper et al., 2020) or conforming its own subgenus as Otodus (Megaselachus) (Cappetta, 2012; Razak \& Kocsis, 2018). Because of its distinctiveness and still debated phylogenetic position, we refer to it as Carcharocles megalodon following the proposal of Jordan \& Hannibal (1923).

\section{GEOLOGICAL SETTINGS}

MMDA-101 was found on the beach at the Punta Médanos locality, close to the lighthouse (Figure 2; 36 $52^{\circ}$ '46.39's; $\left.56^{\circ} 39^{\prime} 59.45^{\prime} \mathrm{W}\right)$, Buenos Aires Province, Argentina. The location, together with the presence of signs of marine abrasion and dark manganese stains observed on the crown surface, indicates that the specimen remained under water for some time, with some subaerial exposure on the beach.

The discovery of teeth belonging to Carcharocles megalodon in marine sediments around the world is common (Keyes, 1972). One of the most remarkable cases is a tooth found in 1875 during the journey of the HMS Challenger ship, while it was exploring deep waters near Tahiti (Murray $\&$ Renard, 1891). Two large teeth belonging to C. megalodon were recovered at 2,385 $\mathrm{m}$ depth. Furthermore, C. megalodon findings are not only common on the sea floor, but are also frequently found isolated and eroded on seashores after being transported by the sea from the fossil-bearing layers. In this

Table 1. Linear regressions applied for the possible anatomical positions (L1 to L4) of MMDA-101 taken from Shimada (2002) where $\mathbf{Y}$ is the total length of the body (TL) and $\mathbf{X}$ is crown height (CH). Average value of TL for all positions as well as the formula of Gottfried et al. (1996) for body mass.

\begin{tabular}{lcc}
\hline Tooth position & Regression equation & TL $(\mathrm{m})$ \\
\hline L1 & $\mathrm{y} 1=5.540+11.197 \mathrm{x}$ & 5.8 \\
L2 & $\mathrm{y} 2=4.911+13.433 \mathrm{x}$ & 5.48 \\
L3 & $\mathrm{y} 3=0.464+14.550 \mathrm{x}$ & 5.89 \\
L4 & $\mathrm{y} 4=5.569+17.658 \mathrm{x}$ & 7.2 \\
Average value (meters) & $\frac{\mathrm{y} 1+\mathrm{y} 2+\mathrm{y} 3+\mathrm{y} 4}{4}$ & 6.09 \\
Mass formula (kilograms) & $K G=3.29 \times 10^{-06} x\left(T L^{3.174}\right)$ & 2.279 \\
\hline
\end{tabular}



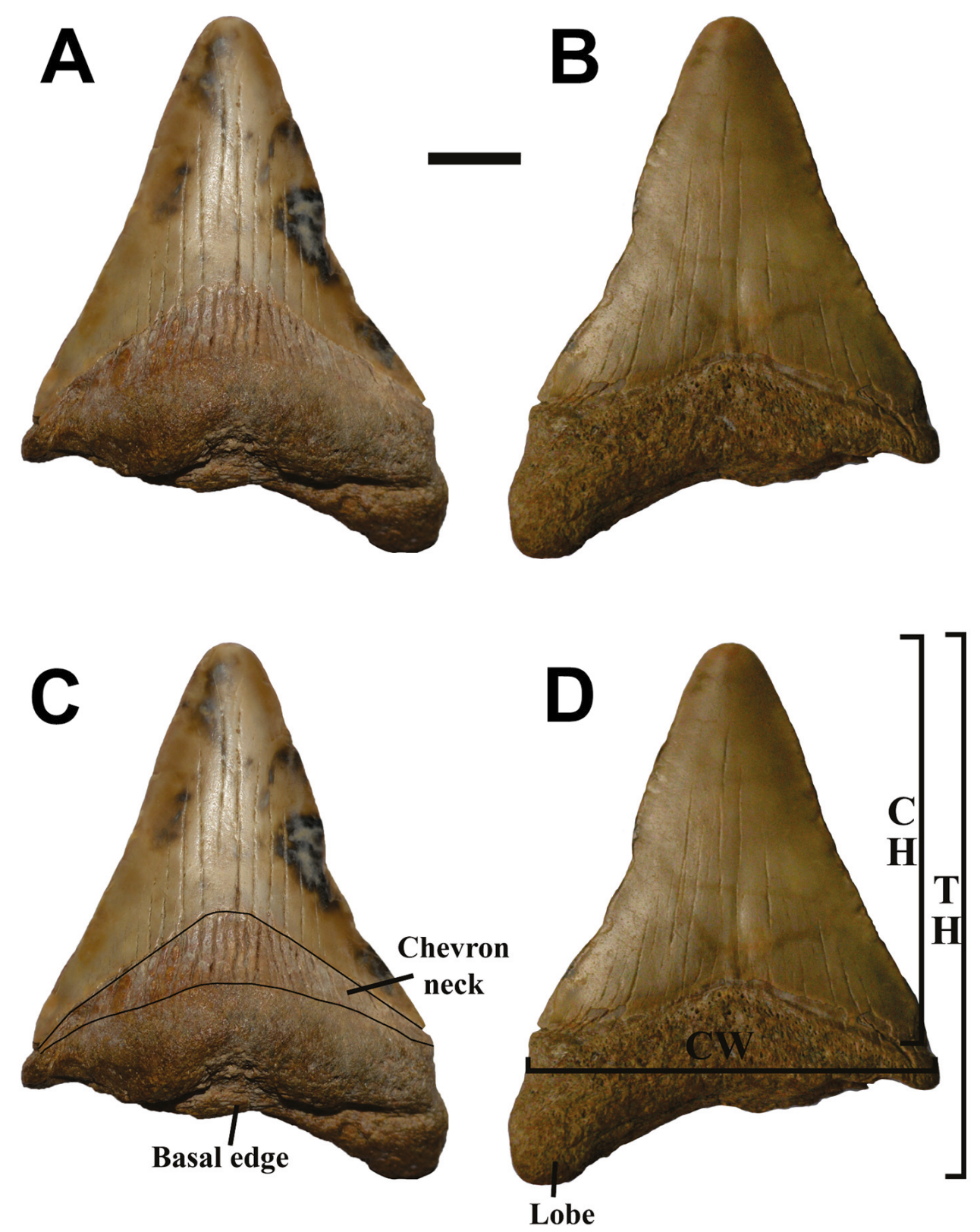

Figure 1. MMDA-101 in lingual $(\mathbf{A}, \mathbf{C})$ and labial $(\mathbf{B}, \mathbf{D})$ views. Crown height $(\mathbf{C H})$, crown width $(\mathbf{C W})$ and tooth height $(\mathbf{T H})$ represent the measurements taken in the specimen. Scale bar $=1 \mathrm{~cm}$.

case, we can mention the findings from Miocene-Pliocene beds from North America (Purdy et al., 2001; Maisch et al., 2020).

Fossil terrestrial megamammals (such as armored xenarthrans and giant sloths) are frequently found along the Bonaerian seashore, with most remains coming from Upper Pleistocene beds at the marine platform (Cione et al., 1999; Tonni \& Cione, 1999). These specimens are found mixed on the same beaches with other marine vertebrates coming from more recent Holocene beds (e.g. Cione, 1983; Cione \& Barla, 2008). However, the age of the specimens described here is uncertain because the geology of the marine platform is rather complex and includes a succession of diverse stratigraphic units. Parker et al. (2008) made an extensive sampling of the marine sediments along the Argentine coast. Near Punta Médanos, Parker et al. (2008) found five depositional sequences (DS): DS5 Upper Pliocene, DS4 Upper Pliocene-Lower Pleistocene, DS3-2 Pleistocene and DS1 Holocene. DS4 is the predominant marine layer exposed in the region when compared with the other sequences. Since Carcharocles megalodon lived from the middle Miocene through Pliocene (and some unconfirmed reports for Pleistocene sediments; Applegate \& Espinosa-Arrubarrena, 1996; Gottfried et al., 1996; Purdy, 1996; Pimiento et al., 


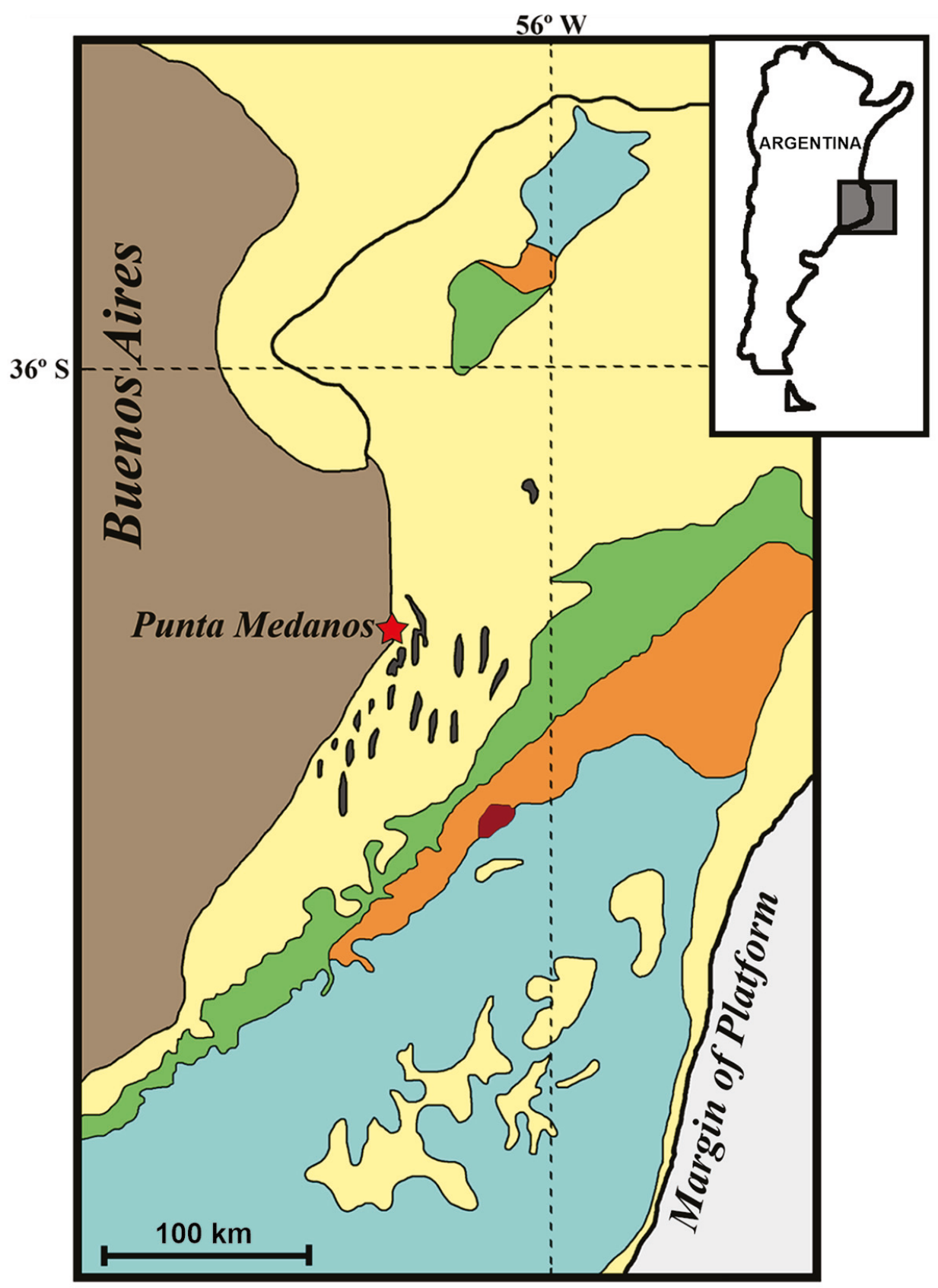

Figure 2. Geologic map based on and modified after those published by Parker et al. (2008). The different strata (depositional sequences or DS) discussed in the text are highlighted in different colors: DS5 (purple; Upper Pliocene); DS4 (light blue; Upper Pliocene-Lower Pleistocene); DS3 (orange; Pleistocene); DS2 (green; Pleistocene); Buenos Aires Formation (dark grey; Pleistocene); and DS1 (yellow; Holocene). Red star shows the fossiliferous locality. Brown color represents the Buenos Aires Province.

2010; 2013; Pimiento \& Clements, 2014; Boessenecker et al., 2019), it is possible that the tooth here described comes from Pliocene beds, probably DS5 or DS4 of Parker et al. (2008) (light blue areas in Figure 2).

Possibly some of the above-mentioned stratigraphical units, such as DS5 or DS4, may be correlated to the sandy beds informally known as the "Puelchense" (see Parker et al., 2008). The "Puelchense" beds are partially correlated with Miocene-Pliocene beds close to Paraná city based on its fossil record (see discussion in Cione et al., 2005; Cione \& Barla, 2008) and belong to a subterranean aquifer that extends along a large portion of the subsoil of Buenos Aires Province, up to the Mar de Ajó locality (see also Auge et al., 2002). The "Puelchense" beds yielded several fossils studied by Carlos Rusconi in the 1930s during the extraction of sand destined for construction (Rusconi, 1933; 1934; Cione \& Barla, 1999; Chimento, 2012). However, since the fossils were extracted with a suction tube, the specimens described 
by Rusconi lacked any stratigraphical control. Interestingly, among "Puelchense" fossils, Rusconi described and illustrated several extinct sharks, such as Carcharias acutissima, Carcharodon hastalis and Carcharhinus spp. (Rusconi, 1948; 1949; Cione et al., 2005). On this basis, it is possible that the Carcharocles megalodon tooth described here may belong to any of the above-mentioned MiocenePliocene beds.

\section{SYSTEMATIC PALEONTOLOGY}

\author{
CHONDRICHTHYES Huxley, 1880 \\ LAMNIFORMES Berg, 1858 \\ OTODONTIDAE Gluckman, 1964
}

Carcharocles Jordan \& Hannibal, 1923

Carcharocles megalodon Agassiz, 1843

(Figure 1)

Referred material. MMDA-101 (Museo de Mar de Ajó, Mar de Ajó city, Buenos Aires Province, Argentina), upper lateral tooth with partially preserved root.

Description. The specimen is relatively well preserved and only lacks one of the lobes of the root (Figure 1). All the surfaces show good preservation except for the tip of the crown and some of the serrations of the mesial and distal cutting edges, which exhibit signs of marine abrasion. The tooth is relatively small when compared with other materials of Carcharocles megalodon. Regarding the position of this tooth in the jaw, this material differs from those of the lower jaw due to the presence of a relatively wider crown and shallower basal concavity (Pimiento et al., 2010; Viciano et al., 2018). Within the upper jaw, anterior teeth show a notably deep basal concavity, and the posterior teeth show strongly asymmetrical crown and roots (Pimiento et al., 2010; Viciano et al., 2018). Therefore, based on crown and root shape and proportions, MMDA-101 can be determined as being an upper lateral tooth (between L1-L4 positions).

The tooth crown is subtriangular in shape, nearly symmetrical in contour, with a nearly flat labial surface and a notably convex lingual one. It shows serrated mesial and distal cutting edges. In lingual view (Figures 1A, C), the crown is apicobasally tall with a $\mathrm{CH}$ of $40.5 \mathrm{~mm}$, and $\mathrm{CW}$ of $44.5 \mathrm{~mm}$ and shows a TH of $56.1 \mathrm{~mm}$. It shows apicobasally oriented linear striations. At the base of the crown, a typical chevron-shaped band is present. This band is medially thick and becomes narrower towards the mesial and distal edges of the crown. It shows numerous linear striations and is also basoapically oriented. The root is apicobasally convex and shows a rugose surface. The lingual protuberance is gently convex and is devoid of a nutrient foramina and groove. The basal concavity that separates the root lobes is shallow. The only preserved root lobe is relatively small, and it is not strongly basally projected. The root shows a mesiodistally oriented groove that runs across the tooth, which may be the result of marine abrasion. In labial view (Figures 1B, D), the apicobasal crown striations are fewer and shallower than those of the lingual surface. The root shows a nearly flat, rugose surface that is covered by small pores as a result of marine abrasion.

\section{DISCUSSION}

As indicated above, in spite of marine abrasion, the specimen MMDA-101 is confidently identified as Carcharocles megalodon on the basis of the following combination of characters: relatively large crowns which are subtriangular in contour, with a convex lingual surface and a nearly flat labial surface, presence of a chevron-shaped band on the lingual surface separating the root from the crown, poorly developed lingual protuberance of roots, and well-differentiated root lobes separated by a shallow basal concavity (Gottfried et al., 1996; Pimiento et al., 2010; Cappetta, 2012; Cione et al., 2012; Medina-Gavilán et al., 2015; Boessenecker, 2016; Viciano et al., 2018). Furthermore, the $\mathrm{CW}$ and $\mathrm{CH}$ of MMDA-101 fall within the morphological cloud of C. megalodon carried out by Pimiento et al. (2010) (Figure 3A). Therefore, the identification of MMDA-101 as C. megalodon is supported by quantitative and qualitative information.

MMDA-101 is smaller than adult specimens of Carcharocles megalodon, but it is also much bigger than the great white shark (C. carcharias; Gottfried et al., 1996; Cione et al., 2012). Teeth of juvenile specimens of $C$. megalodon have been documented several times, and a paleo-nursery referred to this species has been recognized from the Gatun formation in Panama (Gottfried et al., 1996; Pimiento et al., 2010). Because of its relatively small size, we included the specimen MMDA-101 in the data matrix of the analysis by Pimiento et al. (2010) which compares the different life stages of the species. This analysis compares the $\mathrm{CH} v s$. $\mathrm{CW}$ from adult and juvenile individuals of $C$. megalodon, showing that this species changes its tooth-measurements during its life. In this sense, the size range for juvenile specimens of $C$. megalodon falls within 4-10 m long.

Based on $\mathrm{CH}$, we estimated the total length of the specimen MMDA-101 following the regression analyses proposed by Shimada (2002). As noted above, the specimen could have many positions within the jaw (L1-L4). For this reason, we calculated the regression for the four possible positions and their average (Figure $3 \mathrm{C}$ ). The resulting length estimate for the specimen is approximately $6 \mathrm{~m}$ (Figure 3B), which falls within the range of sizes of juvenile specimens of Carcharocles megalodon proposed by Pimiento et al. (2010). Finally, we estimated the body mass following the formula proposed by Gottfried et al. (1996). The resulting weight is approximately 2,279 kilograms for MMDA-101, which also fits within the juvenile category of other specimens of equivalent length of C. megalodon (Viciano et al., 2018).

The fossil record of Carcharocles megalodon in Argentina is limited to a few adequately published findings restricted to 


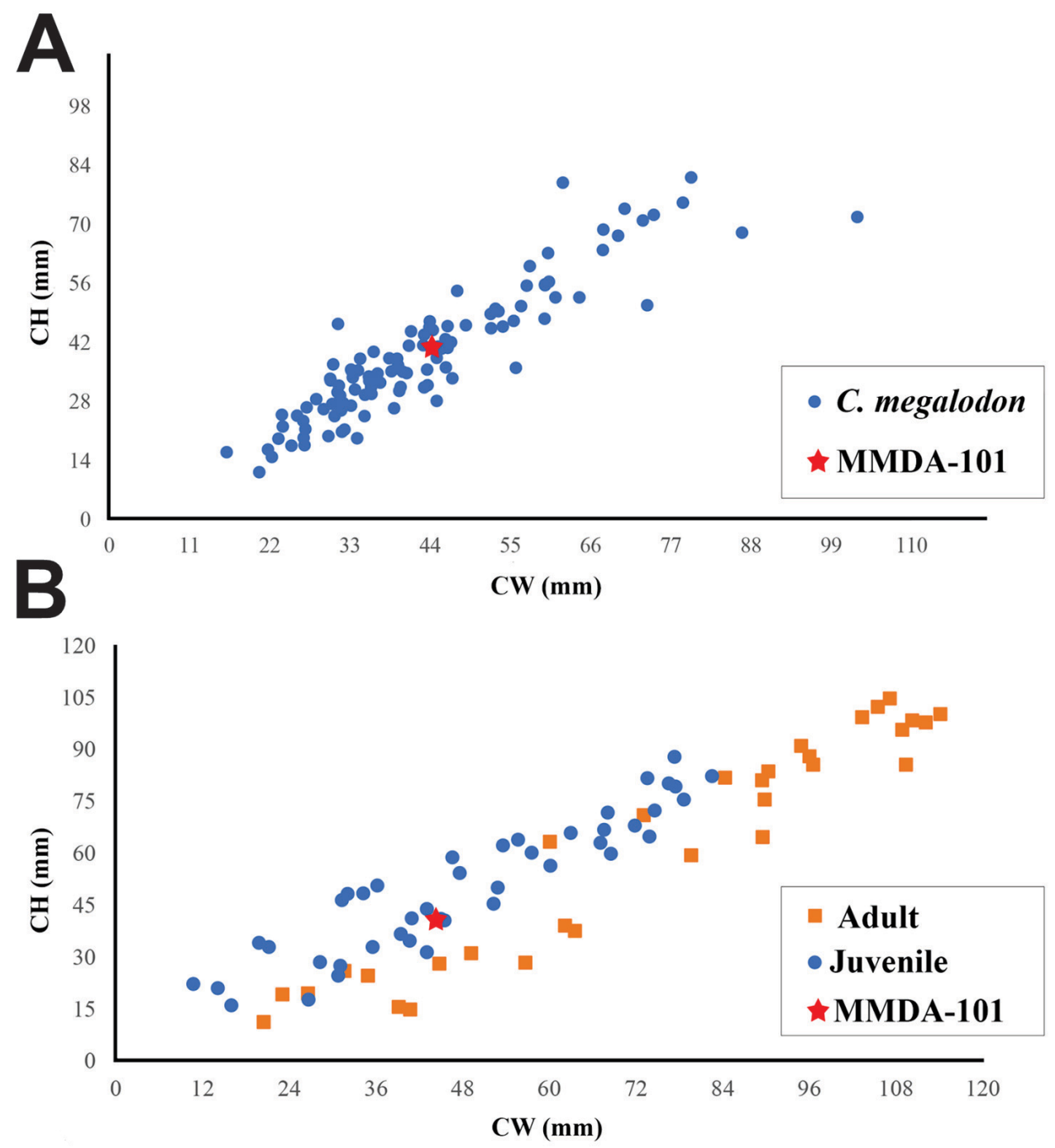

\begin{tabular}{|l|l|r|}
\hline Tooth position & Regression equation & TL $(\mathrm{m})$ \\
\hline L1 & $\mathrm{y}=\mathbf{5 . 5 4 0}+\mathbf{1 1 . 1 9 7} \mathrm{x}$ & $\mathbf{5 . 8}$ \\
\hline L2 & $\mathrm{y}=\mathbf{4 . 9 1 1}+\mathbf{1 3 . 4 3 3 x}$ & $\mathbf{5 . 4 8}$ \\
\hline L3 & $\mathrm{y}=\mathbf{0 . 4 6 4}+\mathbf{1 4 . 5 5 0 x}$ & $\mathbf{5 . 8 9}$ \\
\hline L4 & $\mathrm{y}=\mathbf{5 . 5 6 9}+\mathbf{1 7 . 6 5 8} \mathrm{x}$ & $\mathbf{7 . 2}$ \\
\hline
\end{tabular}

Figure 3. Tooth comparisons in mm of Carcharocles megalodon and MMDA-101 using CW and CH measurements and data of previous work. A, scatter plot showing the anatomical data for C. megalodon (blue dots) published by Pimiento et al. (2010) and MMDA-101 (red star). B, scatter plot showing the anatomical data for juvenile (blue dots) and adult (orange squares) of C. megalodon published by Pimiento et al. (2010) and MMDA-101 (red star).

the Miocene of Entre Ríos Province and Patagonia (Arratia \& Cione, 1996; Cione et al., 2011; Pimiento et al., 2016). MMDA-101 represents the first record of C. megalodon in the Buenos Aires Province and one of the few published findings of the species in Argentina. Furthermore, it constitutes a valuable data point that helps to fill the geographical gap of this poorly known species in the South Atlantic Ocean. It is worth noting that despite the few published records, the presence of C. megalodon in Argentina should not be considered as exceptional, since fossil teeth of the species are not rare in the collections of other paleontological institutions in the country. Although most of these records remain unpublished, most also lack an adequate stratigraphic control, and therefore are of limited value.

Despite the uncertain geochronology of this fossil, we believe that this specimen is of high importance to the paleontological heritage of the Buenos Aires Province and for the reconstruction of the biotic history of the entire area. 


\section{ACKNOWLEDGEMENTS}

We thank S. Lucero and N. Chimento for discussions about the age and record of fossil remains coming from the marine platform and A. Medina Manchento for help with some of the pictures. J.J.D.P. want to thank to F. Novas for encourage and support her during its beginning in research; and S. Biachi for checking the English of the manuscript. We also thank A. Giacchino, Fundación Azara and Universidad Maimónides for their support to this manuscript. Finally, we thank to the editor in chief of the Revista Brasileira de Paleontologia and the anonymous reviewers for helpful suggestions about the MS.

\section{REFERENCES}

Applegate, S.P. 1965. Tooth terminology and variation in sharks with special reference to the sand shark, Carcharias taurus Rafinesque. Contributions to Science, 86:3-18.

Applegate, S.P. \& Espinosa-Arrubarrena, L. 1996. The fossil history of Carcharodon and its possible ancestor, Cretolamna: a study in tooth identification. In: A.P. Klimley \& D.G. Ainley (eds.) Great White Shark. The Biology of Carcharodon carcharias, Academic Press, p. 19-36.

Arratia, G. \& Cione, A.L. 1996. The fossil fish record of Southern South America. In: G. Arratia (ed.) Contributions of Southern South America to Vertebrate Paleontology, München Geowissenschaft Abhandlungen, vol. 30, p. 9-72.

Auge, M.P.; Hernandez, M.A. \& Hernandez, L. 2002. Actualización del conocimiento del acuífero semiconfinado Puelche en la Provincia de Bs. As., Argentina. Groundwater and human development, 624-633.

Boessenecker, R.W. 2016. First record of the megatoothed shark Carcharocles megalodon from the Mio-Pliocene Purisima Formation of Northern California. PaleoBios, 33:ucmp paleobios_32076.

Boessenecker, R.W.; Ehret, D.J.; Long, D.J.; Churchill, M.; Martin, E. \& Boessenecker, S.J. 2019. The Early Pliocene extinction of the mega-toothed shark Otodus megalodon: a view from the eastern North Pacific. PeerJ, 7:e6088. doi:10.7717/peerj.6088

Cappetta, H. 1987. Chondrichthyes II. Mesozoic and Cenozoic Elasmobranchi. In: H.-P. Schultze (ed.) Handbook of paleoichthyology, vol. 3B, Gustav Fischer Verlag, 193 p.

Cappetta, H. 2012. Chondrichthyes (Mesozoic and Cenozoic Elasmobranchii: Teeth). In: H.-P. Schultze (ed.) Handbook of Paleoichthyology, vol. 3E, Gustav Fisher, $512 \mathrm{p}$.

Casier, E. 1960. Note sur la collection des poissons Paléocènes et Éocènes de l'enclave Cabinda (Congo). Annales of Museum Royal Congo Belgium, 30:1-28.

Chimento, N. 2012. Revisión de algunos Xenarthra (Mammalia) del «Puelchense» de la provincia de Buenos Aires, Argentina. Historia Natural, Tercera serie, 2:5-40.

Cione, A.L. 1978. Aportes paleoictiológicos al conocimiento de la evolución de las paleotemperaturas en el área austral del América del Sur durante el Cenozoico. Aspectos zoogeográficos y ecológicos conexos. Ameghiniana, 15:183-208.

Cione, A.L. 1983. Registros fósiles de Carcharodon carcharias (Linné, 1758) (Elasmobranchii, Lamniformes) en Argentina. Ameghiniana, 20:261-264.

Cione, A.L. \& Barla, M.J. 2008. Causes and contrasts in current and past distribution of the white shark (Lamniformes: Carcharodon carcharias) off southeastern South America. Revista del Museo Argentino de Ciencias Naturales "Bernardino Rivadavia", 10:175-184.

Cione, A.L.; Tonni, E.P. \& Dondas, A. 1999. Amastodont (Mammalia, Gomphotheriidae) from the Argentinian continental shelft. Neues Jahrbuchfur Geologi und Palaeontologie, 2005:614-630.

Cione, A.L.; Casciotta, J.R.; Azpelicueta, M.M.; Barla, M.J. \& Cozzuol, M.A. 2005. Peces marinos y continentales del Mioceno del área mesopotámica argentina. Edad y relaciones biogeográficas. Miscelánea, 14:50.

Cione, A.L.; Cozzuol, M.A.; Dozo, M.T. \& Acosta Hospitaleche, C. 2011. Marine vertebrate assemblages in the southwest Atlantic during the Miocene. Biological Journal of the Linnean Society, 103:423-440. doi:10.1111/j.1095-8312.2011.01685.x

Cione, A.L.; Cabrera, D.A. \& Barla, M.J. 2012. Oldest record of the great white shark (Lamnidae, Carcharodon; Miocene) in the Southern Atlantic. Geobios, 45:167-172. doi:10.1016/j. geobios.2011.06.002

Cooper, J.A.; Pimiento, C.; Ferrón, H.G. \& Benton, M.J. 2020. Body dimensions of the extinct giant shark Otodus megalodon: a 2D reconstruction. Scientific Reports, 10:1-9. doi:10.1038/ s41598-020-71387-y

Ehret, D.J.; Hubbell, G. \& MacFadden, B.J. 2009. Exceptional preservation of the white shark Carcharodon (Lamniformes, Lamnidae) from the Early Pliocene of Peru. Journal of Vertebrate Paleontology, 29:1-13. doi:10.1671/039.029.0113

Frenguelli, J. 1920. La ictiofauna terciaria de Entre Ríos. Boletín de la Academia Nacional de Ciencia, 24:1-32.

Glukman, L.S. 1964. Sharks of the Paleogene and their stratigraphic significance. Moscow, Nakua Press, $266 \mathrm{p}$.

Gottfried, M.D.; Compagno, L.J.V. \& Bowman, S.C. 1996. Size and skeletal anatomy of the Giant "Megatooth" Shark Carcharodon megalodon. In: A.P. Klimley \& D.G. Ainley (eds.) Great White Sharks: the biology of Carcharodon carcharias, Academic Press, p. 55-66.

Hubbell, G. 1996. Using tooth structure to determine the evolutionary history of the white shark. In: A.P. Klimley \& D.G. Ainley (eds.) Great White Sharks: the biology of Carcharodon carcharias, Academic Press, p. 9-18.

Jordan, D.S. \& Hannibal, H. 1923. Fossil sharks and rays of the Pacific Slope of North America. Bulletin of the Southern California Academy of Science, 22:27-63.

Keyes, I.W. 1972. New records of the elasmobranch C. megalodon (Agassiz) and a review of the genus Carcharodon in the New Zealand fossil record. New Zealand Journal of Geology and Geophysics, 15:228-242.

Maisch, H.M.; Becker, M.A. \& Chamberlain Jr, J.A. 2020. Macroborings in Otodus megalodon and Otodus chubutensis shark teeth from the submerged shelf of Onslow Bay, North Carolina, USA: implications for processes of lag deposit formation. Ichnos, 27:122-141. doi:10.1080/10420940.2019.1697257

Medina-Gavilan, J.L.; Toscano, A.; Muñiz Guinea, F. \& Delgado, F. 2015. First description for a tooth of the giant, extinct shark Carcharocles megalodon (Agassiz, 1835) found in the province of Seville (SW Iberian Peninsula). BV news Publicaciones Cientificas, 4:107-114. doi:10272/12067

Murray, J. \& Renard, A.F. 1891. Report on deep-sea deposits based on the specimens collected during the voyage of HMS Challenger in the years 1872 to 1876. In: Report on the scientific results of the voyage of H.M.S. Challenger during the years 1873-76 under the command of Captain Georges S. Nares and the late Captain Frank Tourle Thomson, Part III, H.M. Governement, 523 p. 
Nyberg, K.G.; Ciampaglio, C.N. \& Wray, G.A. 2006. Tracing the ancestry of the Great White Shark, Carcharodon carcharias, using morphometric analyses of fossil teeth. Journal of Vertebrate Paleontology, 26:806-814. doi:10272/12067

Parker, G.; Violante, R.A.; Paterlini, C.M.; Costa, I.P.; Marcolini, S.I. \& Cavallotto, J.L. 2008. Las secuencias depositacionales del Plioceno-Cuaternario en la plataforma submarina adyacente al litoral del este bonaerense. Latin American Journal of Sedimentology and Basin Analysis, 15:105-124.

Pimiento, C. \& Balk, M. 2015. Body size trends of the extinct giant shark Carcharocles megalodon: a deep-time perspective on marine apex predators. Paleobiology, 41:479-490. doi:10.1017/ pab.2015.16

Pimiento, C. \& Clements, C.F. 2014. When did Megalodon become extinct? A new analysis of the fossil record. PLOS ONE, 9:111086. doi:10.1371/journal.pone.0117877

Pimiento, C.; Ehret, D.J.; MacFadden, B.J. \& Hubbell, G. 2010. Ancient nursery area for the extinct giant shark Megalodon from the Miocene of Panama. Plos One, 5:e10552. doi:10.1371/ journal.pone.0010552

Pimiento, C.; González-Barba, G.; Ehret, D.J.; Hendy, A.J.W. \& MacFadden, B.J. 2013. Sharks and rays (Chondrichthyes, Elasmobranchii) from the Late Miocene Gatun Formation of Panama. Journal of Paleontology, 87:755-774. doi:10.1666/12117

Pimiento, C.; MacFadden, B.J.; Clements, C.F.; Varela, S.; Jaramillo, C.; Velez-Juarbe, J. \& Silliman, B.R. 2016. Geographical distribution patterns of Carcharocles megalodon over time reveal clues about extinction mechanisms. Journal of Biogeography, 43:1645-1655. doi:10.1111/jbi.12754

Purdy, R.W. 1996. Paleoecology of fossil white sharks. In: A.P. Klimley \& D.G. Ainley (eds.) Great White Sharks: the biology of Carcharodon carcharias, Academic Press, p. 67-78.

Purdy, R.W.; Schneider, V.P.; Applegate, S.P.; McLellan, J.H. \& Meyer, R.L. 2001. The Neogene sharks, rays, and bony fishes from Lee Creek Mine, Aurora, North Carolina. Smithsonian Contributions to Paleobiology, 90:71-202.

Razak, H. \& Kocsis, L. 2018. Late Miocene Otodus (Megaselachus) megalodon from Brunei Darussalam: body length estimation and habitat reconstruction. Neues Jahrbuch für Geologie und Paläontologie-Abhandlungen, 288:299-306. doi:10.1127/ njgpa/2018/0743

Reolid, M. \& Molina, J.M. 2015. Registro de Carcharocles megalodon en el sector oriental de la Cuenca del Guadalquivir (Mioceno superior, Sur de España). Estudios Geológicos, 71:1-32. doi:10.3989/egeol.41828.342
Rusconi, C. 1933. Apuntes preliminares sobre las arenas puelchenses y su fauna. Anales de la Sociedad Científica Argentina, 116:169-193.

Rusconi, C. 1934. Sexta noticia sobre los vertebrados fósiles del puelchense de Villa Ballester. Anales de la Sociedad Científica Argentina, 117:177-186.

Rusconi, C. 1948. El Puelchense de Buenos Aires y su fauna (Plioceno medio). Publicaciones del Instituto de Fisiografia y Geología, Universidad Nacional del Litoral, 33:1-99.

Rusconi, C. 1949. El Puelchense de Buenos Aires y su fauna (Plioceno medio). Segunda parte. Publicaciones del Instituto de Fisiografia y Geología, Universidad Nacional del Litoral, 36:100-242.

Shimada, K. 2002. The relationship between the tooth size and total body length in the white shark. Journal of Fossil Research, 35:28-33.

Shimada, K. 2019. The size of the megatooth shark, Otodus megalodon (Lamniformes: Otodontidae), revisited. Historical Biology, aop. doi:10.1080/08912963.2019.1666840

Shimada, K.; Chandler, R.E.; Lam, O.L.T.; Tanaka, T. \& Ward, D.J. 2017. A new elusive otodontid shark (Lamniformes: Otodontidae) from the lower Miocene, and comments on the taxonomy of otodontid genera, including the 'megatoothed' clade. Historical Biology, 29:704-714. doi:10.1080/0891296 3.2016.1236795

Tonni, E.P. \& Cione, A.L. 1999. Pleistocene continental mammals from the present marine shelf of Argentina. Current Research in the Pleistocene, 16:134-136.

Uyeno, T.; Sakamoto, O. \& Sekine, H. 1989. The description of an almost complete tooth set of Carcharodon megalodon from a Middle Miocene bed in Saitama Prefecture, Japan. Bulletin of Saitama Museum of Natural History, 7:73-85.

Viciano, J.; López-Lázaro, S. \& D’Anastasio, R. 2018. Dientes fósiles de Carcharocles megalodon: la colección del Museo Universitario de Chieti (Italia). Parte I: Análisis morfométrico. International Journal of Morphology, 36:1378-1385. doi:10.4067/S0717-95022018000401378

Ward, D. \& Bonavia, C. 2001. Additions to, and a review of, the Miocene shark and ray fauna of Malta. Central Mediterranean Naturalist, 3:131-146.

Received in 10 October, 2020; accepted in 24 February, 2021. 